\title{
Kampanye Gerakan Indonesia Diet Kantong Plastik Dalam Membentuk Persepsi Masyarakat Bandung
}

\author{
Budi Setiawan, Dini Salmiyah Fithrah \\ Program Studi Ilmu komunikasi, Fakultas Komunikasi dan Bisnis Universitas Telkom
}

\begin{abstract}
ABSTRAK
Penelitian yang berjudul "Kampanye Gerakan Indonesia Diet Kantong Plastik (GIDKP) Dalam Membentuk Persepsi Masyarakat di Kota Bandung" memiliki tujuan untuk meneliti strategi yang digunakan melalui program Kampanye Rampok Plastik dengan menggali melalui teori proses PR dimulai dari mendefinisikan masalah, perencanaan, bertindak dan evaluasi program. Konsep yang digunakan dalam penelitian ini yaitu public relations, kampanye public relations dan persepsi. Dimana dalam konsep public relations akan menggunakan teori Proses Public Relations yang dikemukakan oleh Allan Center, Scott Cutlip, dan Gleen Broom sebagai teori dasar untuk menganalisis strategi yang digunakan dalam objek penelitian. Selain itu, penelitian ini juga akan menggunakan teori Pembentukan Persepsi yang dikemukakan oleh Jalaluddin Rakhmat. Penelitian ini merupakan penelitian kualitatif deskriptif dengan teknik wawancara. Paradigma yang digunakan dalam penelitian ini yaitu post-positivisme. Hasil penelitian menunjukan bahwa persepsi yang ingin dibentuk yaitu masyarakat mulai menyadari dampak negatif penggunaan kantong plastik. Setelah mengindentifikasi dan menganalisis, kampanye rampok plastik telah mengikuti tahapan dalam proses PR meliputi mendefiniskan masalah, rencana program, bertindak dan evaluasi program. GIDKP juga telah berupaya membentuk persepsi masyarakat dengan menerapkan tiga faktor yaitu perhatian, fungsional dan struktural. Strategi yang digunakan untuk membentuk persepsi masyarakat yaitu strategi pesan, strategi komunikator, dan strategi pengecekan pesan. Namun hasil penelitian juga menunjukan bahwa GIDKP belum melakukan evaluasi secara komprehensif, untuk itu peneliti menyarankan agar GIDKP melakukan public survey untuk mengukur ketercapaian tujuan Kampanye Rampok Plastik.

Kata kunci: Public Relations, Kampanye PR, Persepsi, Kampanye Rampok Plastik, GIDKP.
\end{abstract}

\section{Gerakan Indonesia Diet Kantong Plastik Campaign In Order To Create Public Perception In Bandung}

\begin{abstract}
The research entitled "Gerakan Indonesia Diet Kantong Plastik (GIDKP) Campaign in Order to Create Public Perception in Bandung" has a purpose to research the strategies that used through Kampanye Rampok Plastik program by specifically relating to public relations process theory starting from defining problem, planning, acting, and program evaluation. Public Relations, public reltions campaign and perception are the consepts that is used in this research. Within the public relation, the theory of public relations process developed by Allan Center, Scott Cutlip and Gleen Broom as bases to analyze the strategy used in the research object. The other way around, this research would also be using perceptionforming theory developed by Jalaludin Rakhmat. This research is descriptive qualitative research in doing interview technique. The paradigm that used in this research is postpositivisme. The results of the research showed that the perception that wants to be form that the society start to realize what is the negative impact of using plastic bag. After identifying
\end{abstract}

ISSN: 2548-3242 (cetak), eISSN: 2549-0079 Website: http://jurnal.unpad.ac.id/manajemen-komunikasi 
and analyzing, Kampanye Rampok Plastik have already followed the steps in the PR process with the strategies that used to form the society perception that consist of message strategies, communicator strategies, and message checking strategies. However, the result of the research showed that the GIDKP has not do such comprehensive evaluation. So then, the researcher suggested that GIDKP has allow to do a public survey to measure how is the achievement of their goals from Kampanye Rampok Plastik.

Keywords: Public Relations, PR Campaign, Perception, Kampanye Rampok Plastik, GIDKP

Korespondensi: Budi Setiawan. Universitas Telkom. Jl. Telekomunikasi, Jl. Terusan Buah Batu No.01, Sukapura, Dayeuhkolot, Bandung, Jawa Barat 40257 Email: budisetiawan.me@gmail.com

\section{PENDAHULUAN}

Indonesia dinobatkan sebagai negara penyumbang sampah plastik kelaut terbesar nomor dua di dunia. Menurut data yang diperoleh dari Kementrian Lingkungan Hidup dan Perhutanan, sampah di Indonesia mencapai 175.000 ton/hari (Kemenlh, 2015). Sedangkan di Bandung, produksi sampah mencapai 1500-1600 ton/hari. Bahkan Bandung saat ini kekurangan lahan untuk membuang sampahnya. Beberapa lahan TPA seperti TPA Babakan dan TPA Sarimukti sudah tidak sanggup menampung sampah tersebut (Liputan6.com, 2016)

Pemerintah kota Bandung telah melakukan berbagai upaya untuk menyelesaikan masalah ini. Upaya tersebut seperti pembuatan Perda kota Bandung Nomor 17 tahun 2012, penyuluhan ke masyarakat atau penggalakkan kegiatan pungut sampah. Namun upaya tersebut menjadi kurang signifikan karna persepsi masyarakat kota Bandung dalam pengelolaan sampah plastik yang belum dibentuk dengan baik, sehingga masalah sampah plastik tetap ada. Untuk itu diperlukan strategi yang dekat kepada masyarakat dalam upaya menyelesaikan masalah sampah plastik.

Gerakan Indonesia Diet Kantong Plastik (GIDKP) merupakan perkumpulan nasional yang berfokus untuk mengedukasi masyarakat akan bahaya penggunaan kantong plastik. Sejak resmi berdiri tahun 2013, Gerakan Indonesia Diet Kantong Plastik bersama lembaga penggiat isu lingkungan memiliki tujuan untuk meningkatkan partisipasi masyarakat secara individu maupun lembaga serta menyatukan dampak dari kampanye yang dilakukan. Salah satu program masih aktif dijalankan oleh GIDKP yaitu Kampanye Rampok Plastik. Kampanye Rampok Plastik memiliki perbedaan tersendiri dibandingkan kampanye pada umumnya, dimana kampanye ini bertujuan membentuk awareness namun tidak melakukan sounding kegiatan di media sosial dengan pertimbangan untuk menghindari masyarakat yang mendatangi kampanye hanya untuk mendapatkan tas gratis bukan untuk mendengarkan pesan kampanyenya. Kampanye Rampok Plastik sendiri merupakan kegiatan menukar kantong plastik 
yang digunakan oleh masyarakat dengan tas belanja disertai dengan edukasi bahaya penggunaan kantong plastik (dietkantongplastik.info, 2016).

Menurut Rogers dan Storey kampanye adalah serangkaian kegiatan komunikasi yang terorganisir dengan tujuan untuk menciptakan dampak tertentu terhadap sebagian khalayak sasaran secara berkelanjutan dalam periode waktu tertentu (Rogers dan Storey dalam Ruslan 2008). Dalam konteks pembahasan ini, kampanye akan dilihat dari kaca mata public relations yang mana dalam prakteknya kampanye menjadi program kerja atau strategi dari public relations untuk perusahaan maupun organisasi.

Dalam kaca mata public relations, terdapat berbagai program atau kegiatan salah satunya yaitu kampanye rampok plastik. Kampanye merupakan serangkaian kegiatan komunikasi yang terorganisir dengan tujuan untuk menciptakan dampak tertentu terhadap sebagian khalayak sasaran secara berkelanjutan dalam periode waktu tertentu (Ruslan, 2008: 23). Dalam penelitian ini, kampanye rampok plastik akan dilihat dari kaca mata public relations yang mana pada prakteknya kampanye merupakan program kerja atau strategi dari public relations.

Menurut Joseph R. Dominick (Febriyansyah, 2016), public relations mengimplementasikan kegiatannya pada tiga bidang kajian kerja yaitu mempengaruhi opini publik, komunikasi dan fungsi manajemen.
Hal ini juga dipertegas mengenai kewajiban seorang praktisi PR meliputi sensor of social change, corporate

conscience, communicator, dan corporate monitor (Damayanti, 2013).

Menyadari bahwa masyarakat memiliki persepsi bahwa kantong plastik masih memiliki nilai guna dan tidak berdampak buruk, GIDKP memiliki tujuan untuk merubah persepsi tersebut. Adapun persepsi yang ingin dibentuk oleh GIDKP yaitu masyarakat menyadari bahaya penggunaan kantong plastik. Persepsi sendiri merupakan pengalaman tentang objek atau peristiwa yang diperoleh dengan menyimpulkan informasi dan menafsirkan pesan. Penelitian dari Tansatrisna menjelaskan bahwa terdapat hubungan yang signifikan antara persepsi dan pastisipasi masyarakat dalam mengelola sampah. Dari hasil penelitian tersebut juga menjelaskan bahwa peran pemerintah atau tokoh masyarakat sangat penting dalam membentuk persepsi masyarakat (Tansatrisna, 2014).

Kampanye Rampok Plastik yang dilakukan oleh GIDKP memiliki tujuan salah satunya untuk membentuk persepsi berupa kesadaran masyarakat tentang bahaya penggunaan kantong plastik. Persepsi sendiri adalah pengalaman tentang objek, peristiwa, atau hubungan-hubungan yang diperoleh dengan menyimpulkan informasi dan menafsirkan pesan (Desiderato, 1976:129 dalam Rakhmat 2008: 51). 
Persepsi masyakat kota Bandung mengenai penggunaan kantong plastik masih belum cukup baik untuk membuat masyarakat mengurangi penggunaan kantong plastik. Menurut survey dari kompas, alasan masyarakat tidak membawa tas belanja dikarenakan merepotkan (Kompas.com, 2016). Keberadaan Gerakan Indonesia Diet Kantong Plastik bisa menjadi salah satu solusi untuk membentuk persepsi masyarakat tersebut.

Pada akhirnya, dalam penelitian skripsi ini, peneliti bertujuan mendeskripsikan strategi yang digunakan oleh Gerakan Indonesia Diet Kantong Plastik melalui program Kampanye Rampok Plastik untuk membentuk persepsi masyarakat kota Bandung. Dalam penelitian ini, peneliti lebih berfokus pada salah satu program dari GIDKP yaitu Kampanye Rampok Plastik dengan melihat strategi yang digunakan dalam kampanye ini. Untuk menjawab penelitian ini, peneliti akan menggunakan teori perencanaan kampanye public relations yang dijabarkan oleh Allan Center, Scott Cutlip, dan Gleen Broom (2006), yang terdiri dari empat langkah yaitu mendefinisikan masalah, perencanaan program, bertindak atau berkomunikasi dan evaluasi program.

\section{METODE PENELITIAN}

Dalam sebuah penelitian dibutuhkan sebuah metode yang berguna untuk membantu dan menjalankan penelitian agar lebih sistematis. Menurut Afrizal metode penelitian bermakna sebagai strategi-strategi yang dilakukan oleh para peneliti untuk mengumpulkan dan menganalisis data guna menjawab pertanyaan-pertanyaan penelitiannya (Afrizal, 2014: 12).

Pada penelitian ini, peneliti menggunakan metode penelitian deskriptif kualitatif. Jenis penelitian deskriptif kualitatif adalah penelitian yang bermaksud untuk memahami fenomena tentang apa yang dialami oleh subjek penelitian misalnya perilaku, persepsi, motivasi, tindakan dan lain-lain, secara holistic, dan dengan cara deskripsi dalam bentuk kata-kata dan bahasa, pada suatu konteks khusus yang alamiah dan dengan memanfaatkan berbagai metode alamiah (Moleong, 2005: 6). Dengan kata lain, penelitian ini mencoba untuk menjabarkan pemahamannya atas suatu fenomena dengan cara mendeskripsikan fenomena tersebut.

Subjek dalam penelitian ini yaitu Gerakan Indonesia Diet Kantong Plastik (GIDKP). Dimana Gerakan Indonesia Diet Kantong Plastik (GIDKP) mengonsep dan menjalankan program kerja yang bertujuan untuk mencapai tujuan yaitu penggurangan penggunaan kantong plastik di masyarakat. Salah satu program kerja tersebut yaitu Kampanye Rampok Plastik. Objek dalam penelitian ini yaitu Kampanye Rampok Plastik yang dilaksanakan oleh Gerakan Indonesia Diet Kantong Plastik (GIDKP) 
dalam membentuk persepsi mengurangi penggunaan kantong plastik di masyarakat Bandung.

Dalam penelitian ini peneliti akan melakukan wawancara mendalam dengan beberapa informan yang terlibat di dalam pembuatan konsep hingga pelaksana dari Kampanye Rampok Plastik yang dilakukan oleh Gerakan Indonesia Diet Kantong Plastik. Data yang diinginkan dari hasil wawancara ini terkait strategi tim public relations GIDKP dalam membentuk persepsi masyarakat. Sedangkan untuk melengkapi data primer tersebut, peneliti akan melakukan studi literature pada skripsi atau jurnal yang berhubungan ditambah dengan kajian pada sumber-sumber buku yang terkait serta sumber dari internet.

Penelitian ini menguji keabsahan data dengan cara uji kredibilitas atau kepercayaan terhadap data yang dilakukan dengan triangulasi. Moelong menjelaskan bahwa triangulasi adalah teknik pemeriksaan keabsahan data yang memanfaatkan sesuatu yang lain di luar itu untuk keperluan pengecekan atau sebagai pembanding terhadap data itu. Teknik triangulasi yang paling banyak digunakan ialah pemeriksaan melalui sumber lainnya (Moleong, 2005: 330). Triangulasi yang digunakan yaitu triangulasi sumber yang mana peneliti akan membandingkan dan mengecek balik derajat kepercayaan suatu informasi yang diperoleh melalui waktu dan alat yang berbeda dalam penelitian kualitatif. Tujuannya agar data yang didapat tidak hanya berasal dari satu sumber saja namun juga dari sumber-sumber lain yang berkaitan dengan subjek penelitian.

Peneliti menganalisis data dengan menggunakan teknik analisis data interaktif Miles dan Huberman Punch (1992) (dalam Sugiyono, 2011: 244). Miles dan Huberman Punch menjelaskan bahwa data dianalisis secara interaktif dan berlangsung terus menerus sampai tuntas, sehingga analisisnya menjadi jenuh. Analisis dalam Miles dan Huberman meliputi: (a) Kodifikasi data merupakan kegiatan untuk merangkum, memilih hal-hal yang dianggap pokok, memfokuskan pada hal-hal yang penting, dicari tema dan polanya. Maka dari itu data yang sudah direduksi akan memberikan gambaran lebih jelas untuk mempermudah pengumpulan data lanjutan; (b) Penyajian data, data yang telah direduksi kemudian dilakukan penyajian data. Dalam penelitian kualitatif, penyajian data dapat dilakukan dengan cara uraian singkat, bagan, hubungan antar kategori, flowchart dan sejenisnya. Tahapan ini akan memudahkan pekerjaan peneliti selanjutnya; (c) Penarikan kesimpulan/verifikasi Langkah terakhir yaitu penarikan kesimpulan dan verifikasi. Kesimpulan awal yang dikemukakan masih bersifat sementara dan masih dapat berubah apabila tidak ditemukakan bukti-bukti yang cukup kuat untuk mendukung pada tahap pengumpulan data selanjutnya. Namun 
apabila kesimpulan yang dikemukakan pada tahap awal, didukung oleh bukti-bukti yang valid dan konsisten saat peneliti kembali ke lapangan pengumpulan data, maka kesimpulan yang dikemukakan merupakan kesimpulan yang kredibel.

Penelitian ini akan mengamati Kampanye Rampok Plastik dengan menggali informasi dari pihak Gerakan Indonesia Diet Kantong Plastik yang berlokasi di Jalan Tikukur no 6 Bandung Lokasi ini dipilih karena merupakan sekretariat Gerakan Indonesia Diet Kantong Plastik yang ada di Bandung dan di Jakarta. Penelitian in dumulai dari bulan November 2016 hingga Mei 2017.

\section{HASIL DAN PEMBAHASAN}

Terdapat beberapa permasalahan yang ada di masyarakat sehingga menjadi latar belakang kemunculan GIDKP. Masalah pertama yaitu penggunaan plastik yang tidak bijak oleh masyarakat karena didapat secara mudah dan gratis. Hal ini dipicu oleh persepsi masyarakat yang menganggap bahwa kantong plastik baik-baik saja sehingga masih sering digunakan untuk membungkus makanan, membawa barang atau sebagai tempat sampah. Hal ini pula yang GIDKP percayai sebagai penyebab terjadinya tragedi longsor sampah di Tempat Pembuangan Akhir (TPA) Leuwi Gajah yang menewaskan 150 korban jiwa. Masalah kedua yaitu kondisi sampah di Bandung yang sudah mendesak untuk diselesaikan. Seperti yang disampaikan oleh
GIDKP bahwa terdapat 1500-2000 ton sampah di Bandung per hari, dimana $15 \%$ nya merupakan sampah plastik. GIDKP pernah melakukan sebuah survei pada tahun 2009 dengan hasil bahwa setiap masyarakat Indonesia mengonsumsi 700 lembar kantong plastik. Masalah ketiga yaitu pemerintah belum membuat sebuah kebijakan yang mampu mendesak masyarakat mengurangi penggunaan kantong plastik, sekalipun ada kebijakan tersebut bias atau tidak implementatif.

Kegiatan mendefiniskan masalah yang dilakukan oleh GIDKP ini sesuai dengan yang dipaparkan oleh Cutlip, Center \& Broom (2006: 35) bahwa mendefinisikan masalah menjadi pondasi awal sebuah kegiatan berlangsung. Pada fungsinya, hal ini akan mencerdaskan organisasi, ditambah dengan keputusan GIDKP untuk melakukan survei sehingga mengetahui gambaran situasi yang terjadi di masyarakat dan alasan masyarakat bersikap demikian.

Sebagaimana yang dijelaskan oleh informan ahli bahwa, Gerakan Indonesia Diet Kantong Plastik dalam merumuskan masalah, lebih condong ke arah pendekatan hybrid. Pendekatan hybrid yaitu pendekatan yang melakukan riset, baik riset primer (dilakukan sendiri) atau riset sekunder (dari temuan), untuk menggali dan mengenali masalah yang ada sehingga muncul sebuah solusi untuk permasalahan tersebut. Kemudian terdapat proyeksi dari program yang sudah ada untuk 
menyelesaikan masalah yang ditemukan. Hal ini sejalan dengan cara GIDKP mendefiniskan masalah yang dimulai dengan riset pada tahun 2009 diikuti dengan temuan data yang dikeluarkan oleh pemerintah atau dokumen-dokumen sehingga memunculkan solusi untuk masalah tersebut yaitu pembentukan GIDKP. Dari pembentukan ini muncul beberapa proyeksi program yang dianggap mampu untuk memecahkan masalah yang ada, termasuk program Kampanye Rampok Plastik.

Tujuan pelaksanaan Kampanye Rampok Plastik yaitu menyadarkan masyarakat akan bahaya penggunaan kantong plastik dan membiasakan untuk menggunkan tas belanja. Dalam praktiknya, GIDKP menganggap bahwa masih ada masyarakat yang bisa jadi sudah mengenal atau belum mengenal isu kantong plastik, untuk itu awareness masyarakat sangat penting untuk dibangun. Sebagaimana diterangkan dalam Cutlip, Center \& Broom (2006: 35) bahwa dalam merencanakan pogram harus terdapat tujuan dari kegiatan yang dilaksanakan tersebut. Tujuan dari Kampanye Rampok Plastik ini juga sesuai dengan definisi kampanye public relation dalam arti sempit yang disampaikan oleh Rosady Ruslan (2008) bahwa kampanye public relations bertujuan untuk meningkatkan kesadaran dan pengetahuan khalayak sasaran untuk merebut perhatian serta menumbuhkan persepsi atau opini yang positif.
Menurut pandangan dari informan ahli mengatakan bahwa kampanye public relations harusnya berfokus pada satu tujuan yang ingin dicapai, baik itu awareness, interest, desire dan attitude. Namun tidak mungkin jika dalam kampanye tersebut ingin mencapai dua tujuan seperti merubah perilaku dan awareness. Namun seharunya tujuan kampanye ini bertahap dimulai dari membangun awareness hingga merubah perilaku. Selain itu tujuan dari kampanye tersebut harus measurable sehingga mempunyai gambaran jelas. Dengan demikian dapat disimpulkan bahwa Kampanye Rampok Plastik telah memiliki tujuan yang bertahap seperti kampanye yang sering dilakukan pada umumnya. Meskipun dalam kesempatan wawancara dengan informan GIDKP belum menunjukan adanya measurement dari tujuan tersebut.

Khalayak yang disasar oleh GIDKP yaitu masyarakat yang membawa kantong plastik yaitu ibu-ibu rumah tangga dan mahasiswa yang keduanya berada pada golongan ekonomi B dan C. Dalam pembahasan rencana program yang disampaikan oleh Cutlip, Center \& Broom juga dijelaskan bahwa PR harus merumuskan siapa yang akan dijadikan sasaran dari komunikasi yang dilakukan ini. Hal ini diperkuat oleh pernyataan ahli yang mengatakan bahwa penentuan sasaran kampanye dapat dirumuskan lewat geografi dan demografi atau merujuk dari hasil riset sebelumnya. 
Frank Jefkins juga menyampaikan bahwa terdapat beberapa khalayak sasaran dalam program public relation beberapa diantaranya yaitu masyarakat luas dan konsumen pengguna suatu produk. Hal ini diperkuat oleh pernyataan ahli yang mengatakan bahwa penentuan sasaran kampanye dapat dirumuskan lewat geografi dan demografi atau merujuk dari hasil riset sebelumnya.

Adapun saluran komunikasi yang digunakan dalam kampanye ini yaitu media sosial seperti Instagram, Twitter dan Facebook. Ketiga media sosial ini dianggap memiliki pasar yang berbeda-beda dan digunakan karna beberapa pertimbangan seperti masih sering digunakan oleh masyarakat dan organisasi luas. Sebuah penelitian yang dilakukan oleh Wahyudin, Ronauli, Elita, Mirawati (2016:125) menunjukkan bahwa iklan atau kampanya baik melalui media sosial berpengaruh terhadap sikap dan gaya hidup masyarakat.

Saat melaksanakan Kampanye Rampok Plastik, komunikator kerap kali meminta target untuk melakukan update ke media sosial dengan di hubungkan ke media sosial dari GIDKP. Penggunaan media sosial ini sudah dianggap baik bagi GIDKP dan untuk Kampanye Rampok Plastik tetap akan menggunakan Instagram, Twitter dan Facebook.

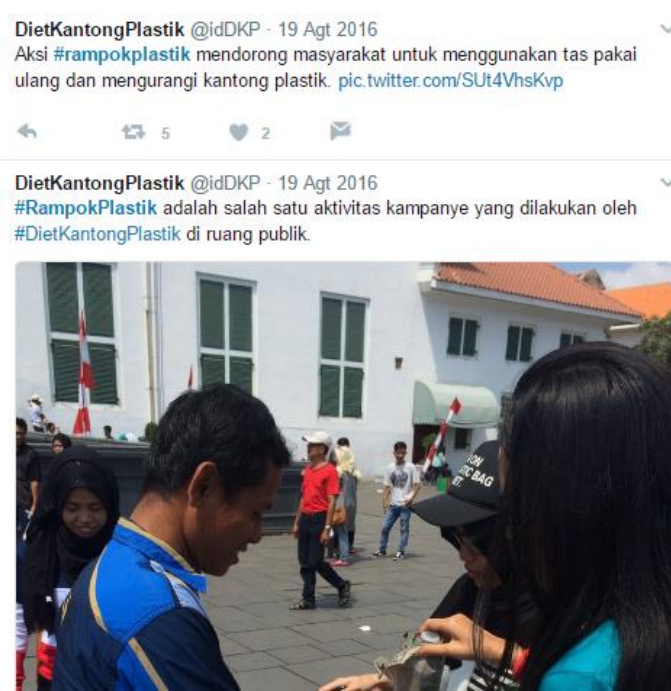

Sumber: Twitter resmi Gerakan Indonesia Diet Kantong Plastik (@idDKP, 2016)

Gambar 1 Dokumentasi Kegiatan Kampanye Rampok Plastik

Gerakan Indonesia Diet Kantong Plastik menetapkan beberapa strategi yang akan digunakan untuk mencapai tujuannya. Strategi tersebut yaitu penetapan pesan kampanye, persiapan komunikator, pendekatan dan pengecekan pesan ke khalayak. Baik Koordinator Regional maupun Koordinator Nasional akan merancang dan menetapkan pesan yang akan disampaikan dalam Kampanye Rampok Plastik yang harus disampaikan oleh komunikator ke khalayak. Pesan tersebut akan di sebarkan kepada komunikator melalui Watsapp group dan saat briefing. Hal ini 
dilakukan guna menyeragamkan pesan yang akan diberikan kepada khalayak. Adapun pesan yang biasanya digunakan sebagai 'pakem' atau pedoman yaitu membiasakan membawa tas belanja sendiri. Pesan tersebut dibentuk dengan diskusi antar Koordinator.

Dengan mengandalkan tenaga relawan sebagai komunikator, GIDKP melakukan perekrutan untuk mendapatkan relawan yang memenuhi kriteria. Syarat menjadi relawan GIDKP yaitu laki-laki atau perempuan usia maksimal 30 tahun mampu berbaasa Indonesia dengan baik dan berbahasa inggris sebagai nilai tambah. Selain itu relawan harus memiliki wawasan luas dan pengalaman di organisasi dengan domisili di Bandung dan Jakarta. Adapun prinsip relawan GIDKP yaitu mampu berinteraksi dengan publik, memiliki sikap mandiri, komitmen, aktif, pemberdayaan, tanpa pamrih, bertanggung jawab, tangkas, partisipatif dan kooperatif. Kemudian akan dilakukan dilakukan pelatihan seperti materi tentang kantong plastik dan simulasi atau role play agar relawan percaya diri untuk berbicara pada khalayak. Sebagaimana perekrutan pada umumnya, GIDKP juga memiliki mekanisme perekrutan dimulai dari distribusi informasi sampai dengan masa pelatihan kepada relawan yang terpilih. Hal ini dilakukan karna GIDKP sadar bahwa strategi mereka yaitu menyiapkan komunikator untuk berani berbicara dihadapan publik.
Saat melaksanakan Kampanye Rampok Plastik, komunikator akan melakukan pendekatan kepada target dengan cara mengamati situasi kemudian memperkenalkan diri dan meminta izin kepada target untuk menyampaikan maksud dan tujuan. Strategi ini dilakukan untuk membuat target percaya dan nyaman untuk dilakukan rampok plastik. Strategi terakhir yang dilakukan oleh GIDKP yaitu melakukan pengecekan pesan yang disampaikan oleh komunikator kepada khalayak sasaran. Pengecekan ini dilakukan oleh Koordinator atau penanggung jawab relawan dengan cara mengamati langsung cara komunikator menyampaikan pesan. Namun GIDKP juga menyatakan bahwa salah satu hambatan yang ada yaitu mengenai waktu untuk rapat dengan relawannya. Selain itu terdapat berbagai respon dari masyarakat saat dilapangan seperti menerima atau bahkan menolak komunikator yang akan melakukan kampanye karna dianggap meminta donasi.

Strategi terakhir yang dilakukan oleh GIDKP yaitu melakukan pengecekan pesan yang disampaikan oleh komunikator kepada khalayak sasaran. Pengecekan ini dilakukan oleh Koordinator atau penanggung jawab relawan dengan cara mengamati langsung cara komunikator menyampaikan pesan. Namun GIDKP juga menyatakan bahwa salah satu hambatan yang ada yaitu mengenai waktu untuk rapat dengan relawannya. Selain itu terdapat berbagai respon dari masyarakat 
saat dilapangan seperti menerima atau bahkan menolak komunikator yang akan melakukan kampanye karna dianggap meminta donasi.

Strategi yang digunakan dalam kampanye rampok plastik ini sudah cukup memenuhi kriteria seperti yang disampaikan oleh informan ahli. Terdapat beberapa elemen yang jadi pertimbangan praktisi PR dalam membentuk strategi yaitu analisis situasi, tujuan, cara mencapai tujuan dan teknik dilapangan serta evaluasi strategi tersebut. Dalam konteks ini, kampanye rampok plastik dalam merumsukan strateginya sudah menganalisis masalah yang ada dilapangan kemudian menentukan tujuan yaitu pembentukan awareness dengan pesannya yaitu membiasakan membawa tas belanja. Kemudian teknik yang digunakan yaitu mempersiapkan komunikator dengan cara pelatihan dan simulasi hingga memantau langsung komunikator dilapangan. Diakhiri dengan adanya evaluasi pada strategi tersebut seperti mengevaluasi komunikator dan mengevaluasi keadaan saat pelaksanaan kampanye tersebut.

Dalam buku Manajemen Humas, Rosady Ruslan mengatakan bahwa sebuah program humas harus memilih waktu dan ruang lingkup yang tepat yang menjadi faktor keberhasilan program itu sendiri. Sedangkan Cutlip, Center \& Broom juga menerangkan dalam perencanaan program bahwa waktu dan lokasi harus dipertimbangkan saat melaksanakan kegiatan. Adapun teknis pelaksanaan dalam Kampanye Rampok Plastik dilihat dari waktu dan cara pelaksanaan itu sendiri. Kampanye Rampok Plastik memanfaatkan momentum seperti hari lingkungan hidup, earth hour dan kegiatan momentum lainnya dengan lokasi seperti taman kota dan balai kota.

Adapun teknis pelaksanaan tersebut diawali dengan briefing dengan seluruh tim kampanye. Pada saat briefing akan dijelaskan kembali tugas-tugas yang harus dilakukan. Dalam briefing juga mulai dibagi tim yang terdiri dari dua hingga tiga orang dengan jumlah tas yang dibagi rata. Kemudian tim tersebut akan berpencar untuk mencari target yang sesuai yaitu yang membawa kantong plastik. Pada saat pelaksanaan, GIDKP kerap menemukan berbagai macam respon dari masyarakat mulai dari sikap yang terbuka hingga sikap menolak. Selain itu dalam setiap Kampanye Rampok Plastik sering ditemukan masyarakat yang ingin memanfaatkan moment tersebut untuk mendapatkan tas gratis, namun GIKDP mengabaikan masyarakat yang oportunis karena dianggap tidak efektif untuk diedukasi.

Hal ini juga sejalan dengan pertimbangan waktu dan lokasi dalam melaksanakan Kampanye Rampok Plastik seperti yang disampaikan oleh informan ahli. Secara praktis PR, pertimbangan tesebut melihat dari season, availability dan case approach untuk target yang spesifik. Dapat disimpulkan 
bahwa pertimbangan GIDKP dalam menentukan waktu dan lokasi sudah sejalan dengan pertimbangan praktis PR dalam melaksanakan kampanye pada umumnya seperti pertimbangan hari lingkungan (season) dan tempat yang memiliki keramaian (availability).

Rosady Ruslan menerangkan bahwa terdapat beberapa faktor yang harus dipersiapkan untuk membuat sukses suatu program salah satunya yaitu penggunaan atribut atau fasilitas yang in line. Untuk mendukung terlaksananya kegiatan Kampanye Rampok Plastik, atribut atau fasilitas juga memainkan peranan penting. Adapun atribut atau fasilitas yang digunakan dalam Kampanye Rampok Plastik yaitu atribut seperti seragam dengan warna yang sama, topi dan pin GIDKP ditambah dengan monster kresek yang merupakan simbol plastik itu sendiri.

Menurut pandangan praktis PR yaitu informan ahli, atribut dan fasilitas yang digunakan dalam sebuah kampanye harus menceriminkan kegiatan dan program yang dilaksanakan. Sehingga dapat dikatakan bahwa atribut GIDKP seperti penggunaan seragam dan topi sudah mencerminkan identitas pelaku dalam melaksanakan program ini. Selain itu adanya monster kresek juga sudah mencerminkan Kampanye Rampok Plastik yang secara terminologi berarti plastik merupakan sesuatu yang menyeramkan atau ditakuti.

Dalam setiap melaksanakan kegiatan yang dilakukan organisasi atau perusahaan, evaluasi sangat diperlukan guna mengukur ketercapaian tujuan dan mendapatkan kesalahan-kesalahan agar kegiatan selanjutnya dapat berlangsung lebih baik menurut Cutlip, Center \& Broom (2006: 35). Gerakan Indonesia Diet Kantong Plastik melalui program Kampanye Rampok Plastik selalu melaksanakan evaluasi pada acaranya. Evaluasi secara internal dilakukan dengan dipimpin oleh penanggung jawab Kampanye Rampok Plastik yang melibatkan seluruh pihak yang terlibat. Evaluasi dilakukan dengan konsep sharing mengenai kejadian yang ditemukan, kendala dan cara penyelesaian termasuk respon masyarakat.

Gerakan Indonesia Diet Kantong Plastik melalui program Kampanye Rampok Plastik selalu melaksanakan evaluasi pada acaranya. Evaluasi secara internal dilakukan dengan dipimpin oleh penanggung jawab Kampanye Rampok Plastik yang melibatkan seluruh pihak yang terlibat. Evaluasi dilakukan dengan konsep sharing mengenai kejadian yang ditemukan, kendala dan cara penyelesaian termasuk respon masyarakat.

GIDKP menilai bahwa komunikator yang dalam hal ini mendapat bantuan SDM dari relawan, sudah baik dalam menyampaikan pesan kepada khalayak. Tolak ukur dalam keputusan ini didasari pada pengamatan 
langsung project leader atau penanggung jawab yang juga terlibat dalam eksekusi Kampanye Rampok Plastik dengan mengamati pesan yang disampaikan oleh komunikatornya. GIDKP menganggap bahwa tujuan Kampanye Rampok Plastik yaitu menyadarkan masyarakat akan bahaya penggunaan kantong plastik dan mengajak menggunakan tas belanja dirasa sudah tercapai. Tolak ukur yang digunakan untuk menentukan keputusan ini yaitu melihat dari respon masyarakat yang dirampok yang bersiat terbuka dan mampu menjelaskan kembali isi pesan yang telah disampaikan oleh perampok. Dengan mengamati langsung respon masyarakat saat melaksanakan Kampanye Rampok Plastik, GIDKP menganggap bahwa persepsi masyarakat mulai terbentuk bahwa kantong plastik memiliki dampak buruk bagi hidup mereka. Hal ini didasari pada kemampuan masyarakat untuk menerangkan kembali pesan yang sudah disampaikan oleh komunikator.

Dari evaluasi yang dilakukan oleh GIDKP secara internal menyatakan bahwa masih terdapat beberapa hambatan dalam melaksanakan Kampanye Rampok Plastik. Hambatan tersebut seperti sulit untuk menentukan jadwal rapat antara GIDKP dengan relawan, kurangnya jumlah SDM, adanya masyarakat yang masih bersifat oportunis atau memanfaatkan keadaan untuk mendapatkan tas gratis.
Namun seperti yang disampaikan oleh informan ahli yang merupakan praktisi PR, ketentuan dalam melakukan evaluasi dapat dilakukan secara kuantitatif dan kualitatif. Sebuah kampanye seharusnya memiliki evaluasi kuantitatif yang terukur sehingga bisa menjadi pedoman dalam menentukan apakah kampanye berhasil atau tidak, untuk memperkuat evaluasi kualitatif. Dimana kata kunci sebuah kampanye yaitu measurable. Sekalipun untuk mengevaluasi komunikator, seharusnya evaluasi tersebut bisa dilakukan secara mendalam dan terperinci. Dimana ada performance evaluation yang dapat dijadikan sebagai parameter dalam megevaluasi komunikator seperti menit keberapa yang berhasil membujuk audience, menit keberapa saat diterima atau ditolak. Dalam pembahasan ini, dapat dikatakan bahwa pertimbangan GIDKP dalam melaksanakan evaluasi masih kurang sesuai dengan pelaksanaan kampanye pada umumnya. Dimana Kampanye Rampok Plastik pada kenyataannya belum melakukan evaluasi kuantitatif yang dapat menjadi tolak ukur indikator keberhasilan kamapanyenya.

Perhatian menjadi faktor yang sangat penting dalam melaksanakan sebuah kegiatan, dimana perhatian akan menentukan ketertarikan khalayak terhadap suatu acara. Melalui perhatian pula proses persepsi seseorang baru dapat terjadi. Perhatian adalah proses mental ketika stimuli atau rangkaian stimuli menjadi menonjol dalam kesadaran 
pada stimuli lainnya melemah (Rakhmat, 2008: 52-58).

Gerakan Indonesia Diet Kantong Plastik menyadari bahwa perhatian menjadi aspek yang sangat penting dalam Kampanye Rampok Plastik, karena jika masyarakat tidak memberikan perhatian maka pesan tidak bisa disampaikan dengan baik. Upaya yang dilakukan dalam Kampanye Rampok Plastik untuk menarik perhatian masyarakat yaitu komunikator menggunakan baju dengan warna yang seragam ditambah dengan hadirnya monster kresek. Upaya lain yang dilakukan yaitu memberikan rangsangan suara seperti yel-yel dan ajakan untuk mengurangi penggunaan kantong plastik. Selain itu, akan hadir konsep baru dalam Kampanye Rampok Plastik yaitu bring back your bag dengan tujuan untuk memberikan peluang masyarakat mendonasikan tas belanja mereka.

Secara praktis PR, sebuah program kampanye sangat membutuhkan perhatian dari audience. Untuk itu cara termudah dalam menarik perhatian yaitu dengan mengidentifikasi karakter audience dan mencocokan diri dengan kebiasaan tersebut. Dalam konteks menarik perhatian yang dilakukan oleh kampanye rampok plasik, cara seperti mengahdirkan monster kresek dan yelyel bisa jadi dapat menarik perhatian karna pada kenyataannya ada personal approach dan crowd approach. Dalam konteks ini, Kampanye Rampok Plastik masuk dalam kategori crowd approach yaitu berupaya menarik perhatian massa.

Faktor internal seperti komunikator, yang dalam hal ini didominsi oleh tenaga relawan, berperan besar dalam membentuk persepsi masyarakat. Faktor fungsional berbicara tentang pengalaman, motif, sifat dan kebiasaan relawan dalam kesehariannya. Faktor fungsional berasal dari kebutuhan, pengalaman masa lalu, dan hal-hal lain yang termasuk apa yang disebut dengan faktorfaktor personal. Yang menentukan persepsi bukan jenis atau bentuk stimuli, tetapi karakteristik orang yang memberikan respons pada stimuli (Rakhmat, 2008: 52-58).

Kampanye Rampok Plastik mendapat bantuan besar dari tenaga relawan. Setiap kegiatan yang berlangsung selalu ada relawan yang membantu. GIDKP mengatakan bahwa relawan saat ini berjumlah 22 orang yang ada di Bandung dan 24 orang relawan yang ada di Jakarta. Rata-rata alasan mereka menjadi relawan karna ingin berkontribusi untuk perbaikan lingkungan. Meskipun pada faktanya bahwa para relawan GIDKP ini berasal dari latar belakang dan concern yang berbeda, bahkan ada relawan yang belum memiliki pengalaman sebelumnya, tidak terlihat perbedaan yang signifikan. Dalam artian perlakuan terhadap seluruh informan sama, hanya yang membedakan yaitu level informasi mengenai isu kantong plastik saja. Meskipun ada yang baru pertama kali menjadi relawan dan bukan berasal dari latar belakang 
lingkungan, hal ini disiasati dengan diadakannya pelatihan selama enam bulan setelah relawan lolos tahap rekruitasi. Dalam proses pelatihan ini, relawan akan mendapatkan materi atau isu-isu tentang sampah plastik, gambaran tentang GIDKP dan pelatihan untuk terjun dalam kegiatan seperti Kampanye Rampok Plastik.

Sebagaimana yang disampaikan oleh informan ahli bahwa dalam sebuah program PR seperti kampanye, kehadiran komunikator sangat berpengaruh besar dalam menyampaikan pesan. Pemilihan komunikator dalam sebuah kampanye harus dapat mempertimbangkan peran dan kecocokan komunikator dengan pesan yang ingin disampaikan. Dalam hal ini, GIDKP memiliki komunikator yang lebih banyak berasal dari tenaga relawan. Hal ini dibenarkan oleh informan ahli karna dalam organisasi masyarakat, relawan cukup diandalkan sebagai komunikator. Dengan adanya pelatihan yang diberikan oleh GIDKP kepada relawan, dirasa cukup untuk membekali relawan sebelum terjun ke lapangan sebagai komunikator.

Pemilihan relawan dengan kriteria tersebut akan mempengaruhi dalam penyebaran pesan kepada khalayak. Hal ini dikarenakan relawan menjadi bagian dari komunikator. Sehingga aspek seperti percaya diri untuk berbicara di depan publik dapat membantu komunikator menyampaikan pesan. Selain itu dengan menerapkan green life style juga akan mempengaruhi lingkungan hidup relawan.

Faktor struktural menjadi faktor yang penting karna akan membantu dalam menciptakan solusi untuk membentuk persepsi masyarakat. faktor struktural ini melihat penilaian dari sisi pelaku terhadap khalayak sehingga dapat menentukan tindakan dalam membentuk persepsi. Faktorfaktor struktural yang menentukan persepsi menurut teori Gestalt bila kita ingin memahami suatu peristiwa kita tidak dapat meneliti faktor-faktor yang terpisah tetapi memandangnya dalam hubungan keseluruhan (Rakhmat 2008: 52-58).

Gerakan Indonesia Diet Kantong Plastik menilai bahwa masyarakat sebenarnya sudah memiliki pemahaman mengenai isu kantong plastik. Namun masyarakat masih belum tahu apa yang harus dilakukan dan bagaimana melakukannya. GIDKP menilai bahwa persepsi masyarakat saat ini masih menganggap kantong plastik baik-baik saja dan masih memiliki nilai guna. Penilaian ini kemudian menjadi salah satu landasan Gerakan Indonesia Diet Kantong Plastik untuk membuat program demi merubah mindset masyarakat yang belum mengetahui tentang isu kantong plastik.

Sedangkan informan ahli menjelaskan bahwa penilaian dari GIDKP ini termasuk dalam klasifikasi pendekatan hybrid. Dimana pendekatan ini menjelaskan terdapat pemahaman masalah yang ada di masyarakat 
secara menyeluruh dan detail yang kemudian ditarik sebuah rekomendasi untuk ditemukan solusinya. Kemudian lahirnya programprogram yang dianggap mampu untuk menyelesaikan permasalan tersebut.

\section{SIMPULAN}

Dalam menjawab fokus penelitian yaitu "Strategi yang digunakan oleh Gerakan Indonesia Diet Kantong Plastik melalui program Kampanye Rampok Plastik", peneliti menganalisis bahwa Gerakan Indoensia Diet Kantong Plastik telah menjalankan proses PR Kampanye Rampok Plastik yang dikemukakan Cutlip, Center \& Broom 2006. Pada tahap mendefiniskan masalah terdapat tiga masalah besar yaitu persepsi, kondisi sampah dan penanganan pemerintah. kemudian definisi ini menjadi pondasi untuk merumuskan tahap kedua yaitu perencanaan program. Dalam tahap kedua ini dirumuskanlah tujuan hingga strategi Kampanye Rampok Plastik meliputi Strategi pesan, strategi komunikator dan pengecekan pesan. Di tahap ketiga GIDKP berkomunikasi dengan menentukan lokasi juga waktu pelaksanaan kegiatan yang di dukung dengan atribut-atribut dan dimulai dengan briefing awal. Selanjutnya di tahap keempat, GIDKP mengevaluasi programnya meliputi evaluasi tujuan, komunikator sampai dengan evaluasi hambatan atau kendala. Namaun pada tahap evaluasi ini masih bersifat internal GIDKP saja. Dari analisis dan pemaparan, dapat disimpulkan bahwa strategi yang digunakan oleh GIDKP dalam Kampanye Rampok Plastik meliputi tiga strategi yaitu strategi pesan, strategi komunikator dan strategi pengecekan pesan..

\section{DAFTAR PUSTAKA}

Afrizal. (2014). Metode Penelitian Kualitatif. Jakarta: PT Raja Grafindo Persada.

Auliani, Palupi Annisa. (2016). Ada Program "Tambahan Harga Kresek", Siap Bawa Kantong Plastik Sendiri?. Kompas. Diakses dari: http://property.kompas.com/read/2016/ 01/27/214000121/Ada.Program.Tamba h.Harga/ tanggal 1 Desember 2016.

Febriyansyah, Andi. (2016). Strategi Media Relations PT. Pelabuhan Tanjung Priok Dalam Menanggapi Krisis. Jurnal Kajian Komunikasi, Vol 4, No 2. DOI: 10.24198/jkk.v4i2.8017

Cutlip, M Scoot. Center, H Allen. \& Broom, M Gleen. (2006). Effective Public Relations. Jakarta: Kencana Prenada Media Group.

Chariri. \& Ghozali, Ahmad. 2007. Teori Akuntansi. Yogyakarta: Penerbit Andi.

Damayanti, Trie. (2013). Persepsi Mahasiswa Tentang Posisi Strategi Profesi Public Relations. Jurnal Kajian Komunikasi, Vol 1, No 1. DOI: 10.24198/jkk.vlil.6032

Jefkins, Frank. (2003). Public Relations. Jakarta: Erlangga.

Kementrian Lingkungan Hidup Republik Indonesia. (2015). Rangkaian HLH 2015 - Dialog Penanganan Sampah Plastik. Jakarta. Diakses dari: http://www.menlh.go.id/rangkaian-hlh2015-dialog-penanganan-sampahplastik/ tanggal 1 Desember 2016.

Moleong. (2005). Metodologi Kualitatif Edisi Revisi. Bandung: PT Remaja Rosdakarya.

Rakhmat, Jalaluddin. (2011). Psikologi Komunikasi. Bandung: PT Remaja Rosdakarya. 
Rakhmat, Jalaluddin. (2008). Psikologi Komunikasi. (pp 51). Bandung: PT Remaja Rosdakarya.

Ronauli, M., Wahyudin, U., Elita, F.U., Mirawati, I., 2016, HUBUNGAN ANTARA PESAN KAMPANYE 9 AKSI RAMAH LINGKUNGAN DI AKUN TWITTER EARTH HOUR BANDUNG DENGAN SIKAP FOLLOWERS AKTIF TERHADAP GAYA HIDUP RAMAH LINGKUNGAN, diakses dari http://jurnal.unpad.ac.id/manajemenkomunikasi/article/view/11017/4924

Ruslan, R. (2008). Kiat dan Strategi Kampanye Public Relations. Jakarta: PT Rosdakarya.

Saokani, Kukuh. (2016). Setiap Hari, 200 Ton Sampah Plastik Banjiri Kota Bandung. Liputan6. Diakses dari: http://regional.liputan6.com/read/2416 636/setiap-hari-200-ton-sampahplastik-banjiri-kota-bandung tanggal 17 November 2016.

Sugiyono. (2011). Metode Penelitian Kualitatif dan $R \& D$. Bandung: Alfabeta.

Tansatrisna, Diwyacitra. (2014). Persepsi dan Partisipasi Masyarakat Dalam Pengelolaan Sampah Rumah Tangga. Skripsi. Dipubliakasi. Bogor: Institut Pertanian Bogor.

Gerakan Indonesia Diet Kantong Plastik. (2016). Tentang Kami. Diakses dari: http://dietkantongplastik.info/tentangkami/ tanggal 12 Maret 2017.

Twitter Resmi Gerakan Indonesia Diet Kantong Plastik. (2016). Dokumentasi Kegiatan Kampanye Rampok Plastik. Diakses dari: https://twitter.com/idDKP tanggal 4 Juni 2017. 